\title{
Packaging Design Of Betutu Chicken Special Merchandise From Bali
}

\author{
Ni Luh Desi In Diana Sari \\ Visual Communications Design Study \\ Program \\ Faculty of Arts and Design ISI Denpasar \\ Denpasar, Bali \\ desiindianasari@yahoo.com
}

\author{
I Nengah Sudika Negara \\ Visual Communications Design Study \\ Program \\ Faculty of Arts and Design ISI \\ Denpasar \\ Denpasar, Bali \\ negarasudika@gmail.com
}

\author{
Alit Kumala Dewi \\ Visual Communications Design Study \\ Program \\ Faculty of Arts and Design ISI \\ Denpasar \\ Denpasar, Bali \\ kumalaisidps@gmail.com
}

\begin{abstract}
The purpose of this design is to create the packaging design of Betutu Chicken as a special souvenir from Bali to tourists. This design is based on the problems that the design of the Betutu Chicken that is used as a souvenir does not meet the criteria. This design is done as a solution to the aforementioned problem by designing a package that is in accordance with the following criteria: 1). Stand Out, 2). Contents 3). Distinctive, 4). Suitable. The design processes are carried out through four stages, the first stage is idea and the second stage includes packaging design, graphic elements on the main display panel. Then proceed to the third stage Feasibility Phase which is a prototyping stage. The result is a prototype of packaging design of Betutu Chicken using environmentally friendly natural material shaped like a full shopping bag with handles. Making it easier for consumers to carry. The result of this design can be used by a restaurant that serves Betutu Chicken culinary as one alternative packaging design for packing Betutu Chicken as a unique Balinese souvenir and the packaging can also be reused.
\end{abstract}

Keywords: Packaging Design, Environmentally Friendly, Betutu Chicken

\section{INTRODUCTION}

Betutu chicken comes from the word tunu which means burned and stringed with the word beyang which means meat. Betutu is defined as burnt meat. The authentic flavor of betutu chicken culinary lies in the combination of base genep which is the Balinese traditional spices consisting of onion, garlic, lemongrass, chili, pepper, pecan, ginger, turmeric, galangal and cutchery which then are chopped and smeared throughout the chicken surface then cooked by burning or steaming. Spicy savory taste is the characteristic of this culinary.

Not only eaten on the spot, betutu chicken culinary can be used as one alternative of a unique Balinese souvenir. To pack betutu chicken culinary as a souvenir, traders still use the packaging that they use to pack the take-home order. The use of plastic materials, recycled paper packaging sold in the market with standard forms and the use of unsafe straps for food still dominate. Overall, the packaging design that is used nowadays still does not meet the criteria especially seen from the graphic elements of packaging in the forms of color, illustration, shape, typography, layout and product information for consumers [1]. Other research results found that one of the visitors' considerations before taking the decision to buy betutu chicken is influenced by the packaging. This packaging is used to pack food brought out of the house or by way of delivery [2]. The graphic elements on the packaging have different functions in the consumer's mind. Forms of packaging, color, typography, illustration, material and packaging quality give a positive influence on sales. The visual aspect becomes most effective in influencing consumer decisions to buy a product [3]. Good packaging design should be able to draw attention visually, emotionally and rationally, so as to add value to the packaged product [4]. Making betutu chicken culinary as one of the icons of Balinese souvenirs to the tourists needs a revamping effort, especially in terms of packaging graphic elements. But the design related to the correction of packaging graphic elements for betutu chicken culinary as souvenirs still has no one to do. Therefore, this design aims to solve the aforementioned problems. The results of this design is expected to contribute in the form of ideal packaging design as a medium for packing betutu chicken culinary as an icon of the typical Balinese souvenirs to tourists as the target audience. Hence betutu culinary is able to compete with typical culinary from other regions and improve the positive image of traditional betutu chicken culinary in the minds of tourists.

\section{DESIGN METHODS}

Methods in designing the packaging design to pack betutu chicken culinary consists of :

\section{A. Idea Stage}

The idea stage begins with the stage of the discovery of ideas in the form of concept which is then used as a reference in the work. Concepts can be understood as a strategic rationale for achieving one goal. Concepts are thoughtful, and not operational. The concept requires implementation and is a plan [5].

Stage of ideas is obtained based on public opinion of the packaging design used to pack betutu chicken culinary. Based on that opinion, the ideas that were ejected then discussed, filtered and selected to find which ideas are appropriate to the needs. At this stage, the first thing to do is the preparation of observation, gathering of information and ideas through several methods, namely:

1). Methods of data collection were conducted to obtain primary data through surveys, observations, and interviews related to the object of design and the source of the idea creation. While the secondary data was obtained through literature review relevant to the subject 
that is being created, namely packaging. This data is used as the theoretical foundation to support the primary data. In addition to literature review, the study of secondary data can be in forms of references of similar works as a reference in the design process to produce the right solutions to solve the problem. The target is to create an ideal packaging as a medium to pack betutu culinary based on design criteria; 1). Stand Out, 2). Contents 3). Distinctive, 4). Suitable.

2). Mind Map on the creation is used as a first step to explore the various sources of ideas that exist in the mind, then poured in the creative notes as an effort to create ideas of creation.

$3)$. The identification of data in this design process uses $5 \mathrm{~W}+1 \mathrm{H}$ (what, why, who, where, when and how) as the foundation of design thinking to solve problems related to design, resulting in critical and creative solutions.

\section{B. Design stage}

At this stage, product formats and information have been determined. All the information required by the designer is outlined in the Packaging Design Brief. The creative process in packaging design to pack betutu chicken culinary consists of several stages including:

1). Thinking Process

2). Research and Analysis

3). Rough Layout

4). Evaluation of Completion

All stages of the creative process above always stood on the study of forms, material studies, color studies, typography, composition / layout and synthesis to determine the selected design.

\section{Feasibility Phase.}

At this stage the prototype components are made using materials and equipment that are similar to the actual conditions [6].

\section{RESULT AND DISSCUSION}

\section{A. Idea Phase}

At the design stage, the packaging that is designed is a suitable packaging design that can be used to pack food. Therefore the shape and packaging materials are selected using food grade materials, minimizing the use of glue and straples that can contaminate the product and harm consumers. The important things to consider before designing the packaging design are grouped into three things:

1). Understanding the culinary character of Betutu Chicken, function, way of presentation and special character.

2). Understanding consumers, including, the target market, target market character, target market need for product packaging, appropriate communication pattern.

$3)$. Design concepts include: what is conveyed, the image of the product that is desired to be built and how to communicate it through packaging [4].

Based on the above brief as an alternative packaging design to pack betutu chicken culinary, it is selected that organic materials functioned as secondary packaging. Natural-based packaging used is a lontar leaf. This packaging is designed in the form of a tote bag (a bag equipped with a long strap as a handle). This refers to the concept of reusable packaging once the product is consumed and reduces the use of environmentallyunfriendly plastic. The selection of the tote bag is intended to fulfill the function of packaging as well as the function of protecting, accommodating, and facilitating the consumer to bring the product. In addition, the selection of tote bag-shaped organic material intended for packaging to pack betutu chicken culinary so that it has a unique, different but still in accordance with the category. Characterized by traditional Balinese feel because the products are packaged in the form of a typical Balinese culinary served as a souvenirs to tourists. Improved appearance of previous packaging appearance is intended to increase product sale value [6]. The choice of lontar material is intended to influence purchasing decisions based on the perception of status because this packaging is used to pack betutu chicken culinary as souvenirs, therefore, the quality of the material and the form of packaging plays an important role to serve as an attraction [3].

In the idea stage, it is also determined the concept of graphic element graphics packaging (Main Display Panel) which functioned as a means of communication and product information to consumers. The Main Display Panel (MDP) is an area located on the front of the packaging design devoted to place brand identity and key communication elements. The packaging graphic elements in the MDP include: brand mark, brand name, product name, ingredient description, net weight, nutritional value information, expiration date, hazard warning, directives for use, dosage, instructions, variety, and barcodes. While the elements are arranged by design which include: colors, images, letters, illustrations, graphic tools, photos (non-information), symbols (noninformation), icons, and visual hierarchy [7].

\section{B. Design Phase}

1). Packaging Design is done through several stages. First is dummy making based on sketch size $25 \times 16 \times 5$ $\mathrm{cm}$, diameter rope handle $14 \mathrm{~cm}$, using locking hook made from coconut shell and hemp rope. The form of packaging takes inspiration from the form of the bag (tote bag) functioned as secondary packaging so it does not require plastic to repackage.

After the dummy is finished, it is continued to the testing stage by inserting the primary packaging into it. The result is the size is appropriate but the hooks are replaced with the lontar material so that it can be in unison with the other lontar material. After going through the revision stage of packaging designed, the tote bag-shaped can be used and is continued to the next step by adding graphical elements in MDP (Main Display Panel) as a means of information and product communication to consumers. 


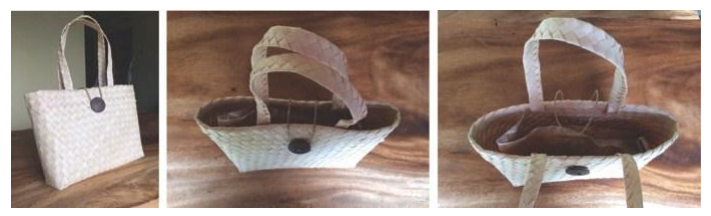

Figure. 1. Making dummy stage 1, packaging design made from organic (lontar leaves) in the form of a tote bag. Source: author document, 2017


Figure. 2. Revision on the dummy hook cover packaging design made from organic (palm leaves) with tote bag shaped. Source: author document, 2017

2). Design of MDP (Main Display Panel) in the form of graphic element of packaging which include: brand name, logo as brand identity, illustration, text, typography, and layout.

a). Brand name is the single most important element in packaging design. Brand name acts as a means of identifying brands and products [7]. Creation of a name starts from making a list of words associated with the product and its personality. Combining words and letters can generate new words. Brand names should reflect product positioning, and should be easy to be remembered by the consumers [7]. The brand name used as culinary identity of betutu chicken in Denpasar city is "Ayam Betutu Denpasar". Giving a name is intended to represent the whole restaurant that provides betutu chicken culinary in the area of Denpasar. As for the brands of each manufacturer can be included on the 'information produced by' in the MDP (Main Display Panel).

Through the brand name "Ayam Betutu Denpasar" it is expected that it is used as a means of promoting and expanding the reach of marketing, and able to influence consumer trust in product quality so as to deliver betutu culinary to get a positive response in the consumers mind [8].

b). Based on its anatomy, the "Ayam Betutu Denpasar" logo is categorized into letter mark type of logo which is dominated by writing, containing words and letters [9]. Stages of design are done by exploring typography that can represent the brand identity, and the type of Goudy Sans Medium Italic BT font was selected. This type of letters communicates the characteristics of Bali, famous for its elegant beauty and cultural arts that are expressive, dynamic and not perceived as rigid. The selection of red and golden yellow color represents Balinese identity which is identical to that color, appropriate, easy to spot, and unique to the brand. This typeface is also easy to be applied, read in different sizes, formats, colors and prints. Here are three alternative logo designs that have been designed and then one is selected for the layout on the MDP (Main Display Panel). In this design the chosen alternative logo design is an alternative logo design 3 (see Fig.3.), With the consideration that, the design of the logotype selected when applied to the MDP (Main Display Panel) is more clearly visible and no one has used it before. Logotype of this type can function as a means of brand communication and product promotion to consumers.

\section{Ayam Betutu Denpasar

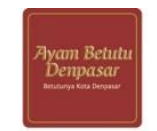 Ayam Betutu Denpasar Desain Logo Alternatif 1
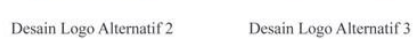

Figure. 3. Alternative logo design as the identity of the brand "Ayam Betutu Denpasar" Source: author document, 2017

c). Illustration as a graphic element of culinary packaging "Ayam Betutu Denpasar" featuring illustrations of betutu chicken products. In addition to product illustrations, the ingredients used to make "Ayam Betutu Denpasar" culinary are also featured as aesthetic elements of packaging, using hand-drawn digital illustration techniques with watercolor painting. The flower icon of Jempiring (cape jasmine) as the mascot of the city of Denpasar is used as the packaging graphic element to inform that this product is a typical Balinese souvenirs from Denpasar city. The use of illustrations is intended to provide information to consumers about product content, product value, consumer appeal to buy products and as a means of brand communication to consumers [3].

All illustrations in layout on MDPs (Main Display Panel) packaging in the form of hang tags and labels are taped over the surface of the primary packaging. The use of hang tags is intended to include product information to consumers. Hang tags are applied by wrapping using a strap on the packaging handle. The size hang tag is $16 \mathrm{x}$ $10 \mathrm{~cm}$, designed in two sides and can be folded. The basic colors of the hang tags is white color to communicate freshness, hygiene, and hygienic. The white color reflects light and makes the surrounding color stand out [4]. The use of white in hang tags can lead consumers to associate brands and symbolize certain values. Color here can function as a tool to communicate the brand and provide value in the consumer mind [3].

The information contained on the front of the hang tag consists of the product brand "Ayam Betutu Denpasar", product explanation, text with the meaning of Jempiring (Cape jasmine) flower as the mascot of Denpasar city and Denpasar city logo, brand guarantee made with stamp illustrations. While information on expiration date, production code, material composition, presentation method, net weight, address and manufacturer's description are included in the inside of the hang tag. 



Figure. 4. Illustrations applied on the main display panel in the form of hang tags and label Packaging of "Ayam Betutu Denpasar"

Source: author document, 2017

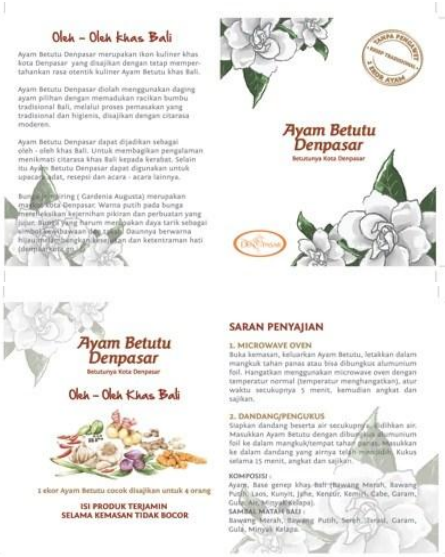

Figure. 5. Design of the MDP in the form of hang tags that are applied on the packaging design the in the form of a tote bag. The top picture is the front view and the bottom picture is the rear view. Source: author document, 2017

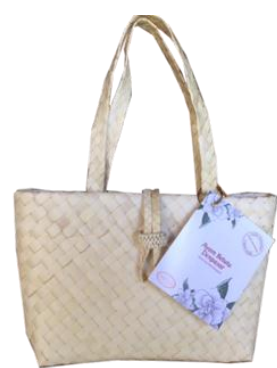

Figure. 6. Application of the MDP in the form of hang tag on the packaging design of the tote bag. Source: author document, 2017

d). MDP's (Main display panel) primary packaging design is designed as a $10 \times 16 \mathrm{~cm}$ label. The information contained on the label consists of the brand name, the Denpasar city logo, the manufacturer's name and address, net weight, expiration date, production code, brand guarantees made with stamped illustrations. Image of Betutu Chicken and its ingredients are used as illustrations that describe the product, these illustrations are made by igital illustration technique. Sequence of information is using layout principles to form sequences like the letter $\mathrm{Z}$, aims to facilitate consumers to read the sequence of information submitted. The use of sequences such as the letter $\mathrm{Z}$ adjusted to the habits of Indonesians reading from left to right, so the information listed on the label of the order of legibility can be systematic.

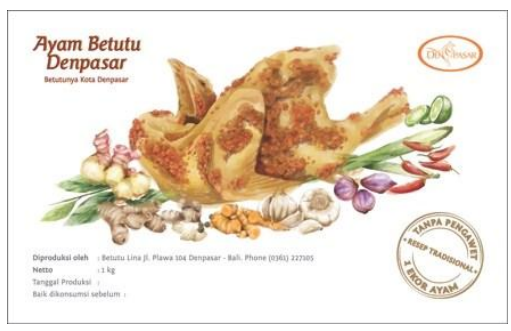

Figure. 7. Design of MDP in the form of sticker label which is applied to the primary culinary packaging design of Betutu Chicken Source: authors document, 2017

\section{Feasibility Phase}

This is the prototype making stage that is using materials and equipment similar to the actual condition of the Betutu chicken culinary packaging design. At the Feasibility Phase, the alternate form of selected packaging design that has been designed then is manifested to its original shape with a 1: 1 scale.

Packing size : $25 \times 16 \times 5 \mathrm{~cm}$, rope handle diameter 14 $\mathrm{cm}$.

Hang tag size : $16 \times 10 \mathrm{~cm}$

Material : Dried Lontar

Printing technique : Digital printing for hang tags and labels

Finishing : Laminated doff


Figure. 8. Prototype of the packaging design. The left image is the front view of the design, the right image is the side view.

Source: author document, 2017

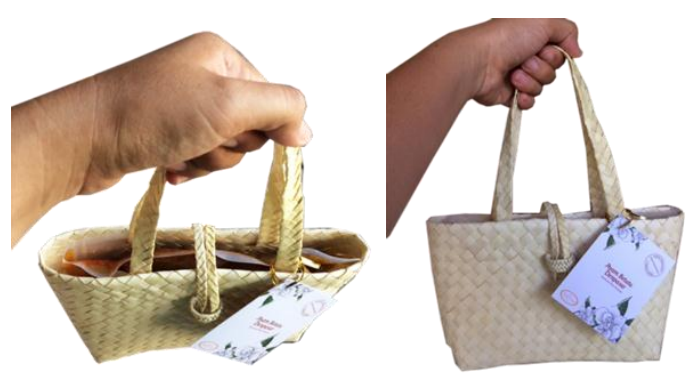

Figure. 9. Prototype of packaging design. Source: author document, 2017

The left picture is the top view of the packaging carrying position and the right picture is the front view of the packaging carrying osition

\section{CONLUSSION}

Through the stages of designing the design package for the betutu chicken culinary as a typical Balinese souvenir, it is produced a packaging design using organic material in the form of palm leaves (lontar) which are 
woven in the shape of a bag equipped with handles to make it easier for tourists to carry. The form of packaging in the form of a bag is used as a secondary package that can replace the presence of plastic bags commonly used by culinary sellers of betutu chicken. The use of plastic materials that do not meet the standards will certainly have a negative impact on food products; in this case Ayam Betutu. Palm leaf as the main raw material for packaging is chosen because this material has advantages over plastic and is easily formed with various designs that are tailored to the needs. This material is also believed not to have a negative impact on products that are packaged because in the processing procedure it does not use chemicals, only soaked with salt water and then dried for further formation.

Besides being functioned as a secondary packaging, the finding of the packaging design has advantages, namely that this packaging can be reused, so that it can reduce waste for the environment. The lontar woven material represents Balinese characteristics because the culinary of betutu chicken is used as a souvenir. The uniqueness and taste of Balinese are raised in this section so that it can be used as one of the attractions besides the graphic elements on the packaging. Through the design of the Betutu Chicken packaging design, it can answer the problems experienced by the Betutu Chicken culinary sellers in Denpasar City. So that this packaging design can be used as an alternative packaging for betutu chicken culinary by sellers. Through a unique, interesting and prominent packaging design as well as communicative information, it can make the betutu chicken culinary as one of the Balinese souvenir icons to tourists so that they can compete with other regional specialties, and build a positive image of traditional culinary in the minds of tourists. This design still needs improvement so that there will be new developments and innovations related to the design of betutu chicken packaging.

\section{ACKNOWLEDGMENT}

Thanks to the Directorate of Research and Community Service of the Directorate General for Research and Development of Research and Technology and Higher Education on the funding provided so that this research can be done. Thank you to the Research Institute of Community Service and Education
Development of Institut Seni Indonesia Denpasar for their cooperation in conducting this research.

\section{REFERENCES}

[1] Desi In Diana Sari, N., \& Pande Sarjani, N. (2017). Characteristics On Culinary Packaging Design Of Ayam Betutu In Denpasar. Mudra Jurnal Seni Budaya,31(3).doi:http://dx.doi.org/10.31091/mudra.v $\underline{31 \mathrm{i} 3.52}$

[2] Suardani, Made. (2011), Analisis Keputusan Pengunjung Membeli Ayam Betutu Pada Rumah Makan Ayam Betutu Khas Gilimanuk Di Tuban Bali, Tesis Pada Program Studi Kajian Pariwisata Program Pasca Sarjana Universitas Udayana.

[3] Vyas, Heer (2015) "Packaging Design Elements and Users Perception: A Contex in Fashion Branding and Commonication," Journal of Applied Packaging Research : Vol. 7: No.2, Article 5. DOI: 10.14448/japr.04.0005

http://scholarworks.rit.edu/japr/vol7/iss2/5

[4] Dameria, Anne. (2014), Packaging Hand Book, Where Creative Ideas Become Reality, Link \& Match Graphic, Jakarta.

[5] Masri, Andri. (2010), Strategi Visual, Jalasutra, Yogyakarta

[6] Julianti, Sri. (2017), A Practical Guide To Flexible Packaging, Material, Teknologi dan Aplikasi, PT. Gramedia Pustaka Utama, Jakarta.

[7] Klimchuk, Rosner \& Krasovec. A. Sandra. (2006), Packaging Design Successful Product Branding From Concept to Shelf atau Desain Kemasan Perencanaan Merek Produk yang Berhasil Mulai dari Konsep Sampai Penjualan, terjemahan Bob Sabran. (2007), Erlangga, Jakarta.

[8] Chandra Lal, Romica; Yambrach, Fritz; and McProud, Lucy (2015) "Consumer Perception Towards Package Design: A Cross Cultural Study," Journal of Applied Packaging Research: Vol. 7: No. 2 , Article

4. http://scholarworks.rit.edu/japr/vol7/iss2/4

[9] Rustan, Surianto. (2009), Mendesain Logo, PT. Gramedia, Jakarta 